Milica Đokić ${ }^{1}$

University of Nis

Innovation center
P. 29-43

SCIENTIFIC REVIEW ARTICLE

Received: February, 12, 2019

Accepted: May, 15, 2019

\title{
SUSTAINABLE AGRICULTURAL AND RURAL DEVELOPMENT IN THE EUROPEAN UNION
}

\begin{abstract}
The agricultural and rural development are issues of great significance in the European Union, which is not surprising considering the fact that around $90 \%$ of the EU territory are intermediate and predominantly rural regions. Therefore, the sustainable agriculture and development of these areas are the main priorities of the member states' Common Agricultural Policy. Adopting measures and practices that will contribute to the productivity growth, while meeting the needs of society and preserving the environment, is an imperative. In order to monitor the effects of implemented measures and to respond properly to the changes, a comprehensive set of indicators has been developed, covering all three dimensions of sustainable agricultural and rural development: economic, social and environmental. They provide a solid information base for defining policies and appropriate strategies, adapted to the characteristics and requirements of a particular area.
\end{abstract}

Key words: sustainability, The EU Common Agricultural Policy, rural development, sustainability indicators

JEL classification: O13, O44, Q56, R11

\section{ОДРЖИВИ АГРАРНИ И РУРАЛНИ РАЗВОЈ У ЕВРОПСКОЈ УНИЈИ}

\begin{abstract}
Апстракт
У Европској Унији питања аграрног и руралног развоја су од велике важности, ито и не чуди ако се узме у обзир чињеница да око 90\% територије ЕУ чине рурална и средюе рурална подручја. Стога, одржсив пољопривреда и развој ових подручја су главни приоритети Заједничке аграрне политике ьених чланица. Усвајање мера и пракси које ће допринети расту продуктивности, али уз истовремено задовољавање потреба друштва и очување животне средине је императив. Како би се пратили ефекти примењених мера и адекватно одговорило на промене, развијен је обиман сет показатеља којима су обихваћене све три димензије одрживог аграгног и руралног развоја:економска, соиијална и еколошка. Уз помоћ юих добија се добра информачиона основа за дефинисане политика и одговарајућих стратегија, прилагођених карактеристикама и захтевима појединих подручја.
\end{abstract}

Кључне речи: одрживост, Заједничка аграрна политика ЕУ, рурални развој, индикатори одрживости

11milica91nis@hotmail.com 


\section{Introduction}

Given the large share of rural areas in Europe and huge number of people involved in this sector, rural development is an important segment of the European Union (EU) policy. Predominantly rural regions occupy more than half of the EU territory (52\%), include $23 \%$ of the EU population and account for $21 \%$ of the employment (EC: Directorate - General for Agriculture and Rural Development, 2013). Those figures are even more significant when regions classified as intermediate are taken into account as well. ${ }^{2}$ Thus, even $90 \%$ of the EU territory is covered by predominantly rural and intermediate regions, which encompass slightly more than half of the population and provide more than $50 \%$ of the employment. However, these numbers vary considerably from country to country. While in some member states more than $80 \%$ of the area is predominantly rural, others do not have these types of region on their territory at all.

Ever since the establishment of the European Economic Community in 1957, the forerunner of today's European Union, agricultural development has been one of the most important issues in the integration. For this reason, from the very beginning, the Common Agricultural Policy (CAP) has been created as a comprehensive policy on agricultural management, agricultural product market and rural development. As circumstances have changed over time, goals and measures of the CAP have been adjusted to emerging needs, so the CAP has undergone some significant reforms. It has always tended to address the current problems - whether if it is market protection and increasing agricultural production, direct payments and measures aimed at improving conditions in rural areas, or promoting sustainable development.

Through the years, it has become clear that economic progress should be achieved with responsible behavior towards the environment, adequate use of natural resources and preservation of the ecosystem. Accordingly, the main CAP objectives have been directed towards the protection of the environment, food safety, preservation of natural resources and sustainable rural development. Particular emphasis is being placed on the production of healthy, high-quality agricultural goods, organic production methods and the use of renewable resources, while preserving biodiversity, reducing environmental pressure and implementing innovations.

The need for measuring sustainable agricultural and rural development has emerged as the subject of sustainable development has become more important and widespread in scientific studies, as well as in the policies of governments and international integrations. Many authors and institutions have tried to give their own perception about the problem and therefore defined various indicators of sustainable agricultural and rural development. Although not significant, there are some differences among them. In order to overcome difficulties due to diversity and large number of indicators, to enable comparison between different countries and regions and to monitor results at the international level, the EU authorities have developed a set of uniform indicators. They provide necessary information pointing out the key areas which need improvement, while helping policymakers in the decision-making process and monitoring the results of the actions taken.

\footnotetext{
${ }^{2}$ In 2010 the European Commission agreed on a new typology of predominantly rural, intermediate and predominantly urban regions
} 


\section{The Common Agricultural Policy reform - from traditional agriculture towards sustainable rural development}

Agriculture and development of rural areas have been the subjects of interest among all member states since the foundation of the Union, covered by the CAP. During all these years, the CAP has undergone numerous changes, some of which have radically affected the direction of further actions and the EU budget. In the middle of the last century, the agricultural sector in Europe was undeveloped, and while revenues in other sectors grew, in agriculture they stagnated. One of the main concerns of the Community was to provide enough food, so subsidies to farmers were given in the form of high support prices, along with strong market protection. However, such measures led to overproduction, and resulted in large surpluses of agricultural goods, some of which were subsidized for export, while the rest had to be stored within the Community, causing high costs. Over the time, number of member states had increased, the EU territory became more diversified and rural areas development began to depend more on other sectors, not just agriculture.

Under the pressure of international organizations, reduction of the price support and liberalization of the agricultural market were inevitable. At the same time, food safety and environmental protection issues became the center of attention. Numerous attempts to change existing goals and measures and introduce new ones had not given desired results until 1992 and the first radical reform of the CAP - McSharry reform - which set the basis for strong rural development policy and determined the further direction of agricultural development. The introduction of direct payments to farmers, instead of the earlier price support, was a major change. It was followed by a rural development plan which involved farms restructuring and agro-environmental protection. In order to adjust the CAP to the EU enlargement, but also to encourage member states to promote growth, new reform - Agenda 2000 - was carried out in 1999. It was primarily focused on increasing the competitiveness of the agricultural sector and improving rural areas. The agricultural sector continued to receive support through direct payments, but these were conditioned by fulfillment of certain environmental requirements. This reform introduced ecological principles to agriculture, which represented a significant step towards sustainable development. Agenda 2000 was focused on the development of multifunctional, sustainable agriculture and rural areas (Božić, Bogdanov, Ševarlić, 2011). Rural development policy was established as the second pillar of the CAP, complementing direct payments and market measures, in the first pillar. The CAP reforms that followed focused on improving competitiveness of the agricultural sector and rural development, and on the measures which promoted food safety, animal protection and conservation of the environment.

The current CAP continues in the same direction. In order to respond to the biggest economic, environmental and territorial challenges, three main long-term objectives have been defined in the CAP 2014-2020 (EC, 2013):

1. Viable food production,

2. Sustainable management of natural resources and climate action and

3. Balanced territorial development.

Promoting sustainable agriculture and adopting environmentally friendly practices is crucial, especially because agricultural production exerts a huge pressure 
on the environment, having a negative impact on human health, animals and plants, endangering their survival. Therefore, the EU agricultural sector is expected to attain a high level of safe and quality food production, while preserving natural resources. Accordingly, the current CAP implies that a large part of the funds intended for farmers is allocated only if they implement appropriate agricultural practices, that are not harmful to the environment.

The CAP also provides a framework for rural development with six common priorities that member states should include into their national programs, based on the need of their territories (EC, 2013):

1. Fostering knowledge transfer and innovation in agriculture, forestry and rural areas,

2. Enhancing farm viability and competitiveness of agriculture in all regions, and promoting innovative farm technologies and sustainable management of forests,

3. Promoting food chain organization, including processing and marketing of agricultural products, animal welfare and risk management in agriculture,

4. Restoring, preserving and enhancing ecosystems related to agriculture and forestry,

5. Promoting resource efficiency and supporting the shift towards a low carbon and climate resilient economy in agriculture, food and forestry sectors,

6. Promoting social inclusion, poverty reduction and economic development in rural areas.

Although the common goals are set, it is not possible to define one single approach that would guarantee a success in achieving sustainability in each country. The heterogeneity of the EU territory has to be taken into account. Therefore, member states are expected to define their own development programs following the given framework, while choosing the measures and strategies for their implementation. This way, each member will be able to put together a set of measures which will respond to the demands and the specifics of the agriculture and rural areas within national borders.

\section{The concept of sustainable agriculture and rural development}

In general, sustainable development is defined as "development that meets the needs of the present without compromising the ability of future generations to meet their own needs" (WCED, 1987). It involves three dimensions: environmental, economic and social. Within agricultural and rural development, these three segments can be described as follows. The environmental dimension refers to the use of natural resources in a way that will not reduce their availability and quality in the future. It also includes protection of rural areas, conservation of biodiversity and the environment, while preventing the use of chemicals and substances harmful to the environment. The economic dimension is related to the efficient use of resources, improvement of the production of raw materials and final agricultural products and the competitiveness of rural areas. Good farming structures, modern technology implementation and rural population employment are some of the important segments in this sphere. The social dimension implies taking care 
of the rural population. It emphasizes the need of maintaining an appropriate working and living conditions and engaging the entire communities in the development, in order to improve quality of life and prevent depopulation of rural regions.

Given that the concept of sustainable agriculture has become widely accepted several decades ago, there are a number of definitions, among which exist minor differences, due to the focusing on different values, priorities and objectives, usually depending on the spatial context. Some authors see sustainable agriculture as "the result of a management strategy which helps the producers to choose hybrids and varieties, a soil fertility packages, a pest management approach, a tillage system, and crop rotation to reduce costs of purchased inputs, minimize the impact of the system on the immediate and the off-farm environment, and provide a sustained level of production and profit from farming" (Francis, Sander, Martin, 1987). Edwards (1987) gave a definition of lower input/sustainable agriculture as "integrated systems of agricultural production that are less dependent on high inputs of energy and synthetic chemicals, and more dependent on intensive management than conventional monocultural systems. These lower-input sustainable systems maintain or only slightly decrease productivity, maintain or increase net income for the farmer, and are ecologically desirable and protective of the environment." Others, discussing sustainable agriculture, focus on the ability of agricultural systems to maintain productivity of crops over the longer period of time (Ikerd, 1993). Some emphasize the factors of sustainability, such as flexibility, which is the ability of agriculture to adapt to future changes (Gafsi, Legagneux, Nguyen, Robin, 2006). Despite the diversity in conceptualization of sustainable agriculture, consensus has been reached on its three basic characteristics: maintenance of environmental quality, stable plant and animal productivity and social acceptability (Rasul, Thapa, 2004).

The complexity of the agricultural and rural sustainability is significant because of the mentioned dimensions and different levels it can be monitored at, from the individual field to the global extent. Particular soil treatments, crop rotation, grazing and cropping practices, pest management and variety of cultivated crops would be the main factors of sustainability at the field level. Appropriate use of resources, living and working conditions may be the key determinants of sustainable rural households and farm business. At the national level, the sustainability might be affected by pressures on the use of agricultural land from non-farming sectors, while at the global level, climate conditions and changes, international terms of trade and distribution of resources also become important determinants (Hayati, Ranjbar, Karami, 2010). National policies and proposed measures significantly influence behavior at the farm level, as well living conditions in rural areas. World market trends and international interventions can also have a huge impact on the lower levels, particularly in the case of undeveloped countries and those where agricultural production is largely dependent on exports. Furthermore, economic, social and environmental goals are often not interrelated, and desired results in one segment are many times attained at the expense of another. Practices that help achieve sustainability in one dimension are not compatible with the sustainability in others. Many farmers, for example, in order to get higher yields, choose aggressive soil treatments and methods which not only degrade the soil and pollute the air, but also disrupt the balance of the ecosystem and threaten the survival of entire species. Focusing primarily on the economic results is usually followed with very hard work and long working hours, so the quality of life is being a matter of concern too. In many low income countries, especially 
overpopulated, where the population pressure is huge, farmers attempt to cultivate land that is not suitable for agriculture. In these cases, achieving short-term economic goals is done at the expense of the environment and long-term ecosystem sustainability. Therefore, agricultural and rural sustainability is largely dependent on what happens at higher levels and on interactions between three components (Norman et al.,1997). The concept of sustainability emphasizes the need to find a proper balance between the three dimensions so further progress towards sustainable agriculture and rural development requires taking into consideration all three spheres, their interrelation and mutual impact when making and implementing policies.

Creating the concept of integrated rural development has made a stronger connection between agriculture and other sectors of the EU economy, as well as society in general, while the concept of sustainability has provided an even better basis for a holistic approach to the problem. The EU rural development policy provides support to the rural areas to deal with current economic, environmental and social challenges. In order to preserve Europe's rural heritage and improve conditions in these regions, a huge attention is dedicated to the protection of biodiversity, preservation of natural landscapes, rational use and management of natural resources, mitigation of climate changes and consequences. Adopted CAP measures promote development of agricultural practices that do not damage the environment and help save rural landscapes. This is achieved by directing the funds to the rural policy procedures that encourage sustainable agricultural practices and by applying sanctions on individuals or households that do not obey the environment protection regulations. The functionality of the EU agriculture and the future sustainability of rural areas include a complex and multidimensional set of interactions between food production and processing, land use and rural economy, environmental management and human health, with which a wide range of scientific, economic, social and educational policies are strongly connected (Tilman, Cassman, Matson, Naylor, Polasky, 2002).

\section{The concept of agricultural multifunctionality}

When it comes to sustainable agriculture and rural development, the multifunctionality of agriculture is often regarded as an important segment, particularly within the EU. The term is not precisely defined, and its interpretation can vary depending on the territory and the context, but it is generally based on the idea that the role of agriculture cannot be limited only to the production of food. In addition, agricultural activity can also shape the landscape, provide environmental benefits, sustainable usage of natural resources, preservation of biodiversity and contribute to the socioeconomic viability of rural areas (OECD, 1998).

The concept of multifunctionality implies that the agricultural sector, besides its primary role of producing food, has other functions that cannot be ignored. Definition of multifunctionality used by the OECD associates multifunctionality with particular characteristics of the agricultural production process and its outputs: i) the existence of multiple commodity and non-commodity outputs that are jointly produced by agriculture and ii) some of the non-commodity outputs may exhibit the characteristics of externalities or public goods, such that the markets for these goods function poorly or 
are non-existent (OECD, 2000). Those non-commodity outputs can be divided into three major groups (Majkovič, Borec, Rozman, Turk, Pažek, 2005). The first one is a group of "new" activities that are more or less related to agriculture, such as: agro-tourism, social services, care activities, etc. Besides them, agricultural production and other associated functions can result in externalities, both positive and negative. Maintaining the cultural heritage, preserving the landscape and providing job opportunities are some examples of the positive effects of agricultural activities, while water and air pollution, soil erosion and destruction of biodiversity appear as negative ones.

Multifunctionality and sustainability of agriculture are interconnected and partly overlap. Both concepts indicate multiple roles of agriculture, including its market and non-market outputs, as well as social and environmental functions. The concept of sustainability emphasizes the importance of maintaining a certain level of resources and welfare over time, extending the perspective to future generations, and therefore is resource-oriented approach. On the other hand, the concept of multifunctionality is considered as an activity-oriented. It looks at the production process of agricultural goods and its contribution to the achievement of societal goals (EC, 2001). The significance of agricultural multifunctionality is recognized by the policymakers in the EU long time ago, as written in the Agenda 2000: "The fundamental difference between the European model and that of our main competitors lies in the multifunctional nature of agriculture in Europe and in the role it plays in the economy and environment, in society, and in the conservation of the countryside; hence the need for maintaining agriculture all over Europe and protecting farmers' income" (EC, 1997).

\section{Indicators of sustainable agricultural and rural development in the European Union}

One of the most important issues related to sustainable agriculture and rural development is how it can be measured. Since it is a comprehensive, multi-dimensional concept, it is difficult to give one single indicator or determine precisely how much some practices are sustainable. Over the past decades, as concerns for the environment were rising and the concept of sustainability became widespread, a number of environmental indicators and methods for assessing the sustainability of the agricultural and rural sector has increased. Precise measurement of agricultural sustainability is not possible, but when specific parameters or criteria are selected, it is possible to determine whether certain trends are stable, moving up or down (Pretty,1995).

Although many authors have proposed definitions and classifications of the indicators, in order to be standardized and suitable for wider use, they had to be formulated at the institutional level. Therefore, certain organizations and integrations, such as the United Nations (UN) and the Organization for Economic Cooperation and Development (OECD) defined their lists of sustainability measures for agriculture and rural sector. Such indicators, globally or regionally accepted, have enabled a comparison between different countries, provided the basis for further international initiatives and have become a policy instrument which puts pressure among countries to achieve better results (Hayati, Ranjbar, Karami, 2010). Development of indicators requires a "systems approach" that would cover 
more than one environmental sphere or theme, and which would try to integrate the full range of interactions between agriculture, environment and social-economic conditions (Piorr, 2003). They are usually grouped within three mentioned segments - the environment, economy and society. The greatest attention is dedicated to the environmental dimension, which is expected considering the enormous impact of the agriculture on the environment. Thus, the largest number of parameters is defined within this sphere.

Sustainable agriculture is time and space-specific concept (Zhen, Routray, 2003). For this reason, the indicators of sustainable agriculture and rural development must be suitable for a particular area. In order to facilitate the monitoring of agriculture and rural development sustainability within the EU and comparing results between member states, the EU authorities have defined a specific set of indicators. They had to meet certain criteria (EC, 2001):

- Policy-relevance,

- Conceptual soundness,

- Definition at an appropriate level of aggregation,

- Effectiveness,

- Statistical validity,

- Analytical soundness,

- Technical feasibility and

- Cost-efficiency.

The environmental protection and rural development issues had to be included into the CAP in an appropriate way, so that set goals could be achieved. To give desired results, adopted measures had to be directed at specific problems, supported by reliable data and their effects regularly evaluated. At the beginning of 2000, the European Commission published the communication "Indicators for the Integration of Environmental Concerns into the Common Agricultural Policy" in which it emphasized the connection and influence of the agricultural sector on the environment and defined goals for monitoring the integration of environmental concerns into the CAP. The Commission relied on indicators and the framework defined by the OECD, adapting it to the agricultural system of the Union. A set of 35 indicators was proposed. Two years later, the IRENA operation (Indicator Reporting on the Integration of Environmental Concerns into Agriculture Policy) was launched by joint efforts of DG Agriculture and Rural Development, DG Environment, Eurostat and DG Joint Research Centre, and the European Environment Agency (EEA) to further develop agri-environmental indicators. The goal was to adapt the proposed list of indicators to different geographical levels and available data and to respond to the individual needs of member states.

Indicators were based on the DPSIR model (Driving force - Pressure - State - Impact Response). DPSIR concept is a framework developed by the EEA to describe and understand relationships between the origins and consequences of environmental problems (EEA, 1999). This model is based on the previous frameworks presented by OECD - the first Pressure-StateResponse (PSR) model and later Driving Force-State-Response (DSR) model (OECD, 1999). In the agriculture, DPSIR model was used to indicate the key issues in the relationship between the agricultural sector and the environment, and to point out major causes and consequences of these relations. The linkage was observed within main agri-environmental segments - water, land use and soil, climate change and air quality, and biodiversity and landscape. At the center of the DPSIR model is the state of the agricultural environment - the current state and how it has changed over time. State indicators point out all undesirable changes that need to be prevented, 
as well as desirable conditions that should be maintained. Then, it is necessary to identify pressures that have led to those undesirable changes in the state or environmental benefits, resulting from agricultural activities. Therefore, the impact on the environment can be negative or positive. The third step is to connect those pressures and processes with the driving forces in the economy, which are directly influenced by agricultural policy. In the end, it is necessary to monitor how society responds to these problems and to check if the agri-environmental measures are helpful and give desirable results. Further work on overcoming problems and constraints in the development indicators resulted in a set of 28 indicators for monitoring the integration of environmental concerns into the CAP.

Table 1. Agri-environmental indicators suggested by the European Commission

\begin{tabular}{|c|c|c|c|}
\hline Domain & Sub-domain & No. & Title \\
\hline \multirow{4}{*}{ Responses } & \multirow{2}{*}{ Public policy } & 1 & Agri-environmental commitments \\
\hline & & 2 & Agricultural areas under Natura 2000 \\
\hline & Technology and skills & 3 & $\begin{array}{l}\text { Farmers' training level and use of environmental farm } \\
\text { advisory services }\end{array}$ \\
\hline & Market signals and attitudes & 4 & Area under organic farming \\
\hline \multirow{13}{*}{ Driving forces } & \multirow{4}{*}{ Input use } & 5 & Mineral fertilizer consumption \\
\hline & & 6 & Consumption of pesticides \\
\hline & & 7 & Irrigation \\
\hline & & 8 & Energy use \\
\hline & \multirow{3}{*}{ Land use } & 9 & Land use change \\
\hline & & 10.1 & Cropping patterns \\
\hline & & 10.2 & Livestock patterns \\
\hline & \multirow{3}{*}{ Farm management } & 11.1 & Soil cover \\
\hline & & 11.2 & Tillage practices \\
\hline & & 11.3 & Manure storage \\
\hline & \multirow{3}{*}{ Trends } & 12 & Intensification / extensification \\
\hline & & 13 & Specialization \\
\hline & & 14 & Risk of land abandonment \\
\hline \multirow{10}{*}{$\begin{array}{l}\text { Pressures and } \\
\text { Risks }\end{array}$} & \multirow{5}{*}{ Pollution } & 15 & Gross nitrogen balance \\
\hline & & 16 & Risk of pollution by phosphorus \\
\hline & & 17 & Pesticides risks \\
\hline & & 18 & Ammonia emissions \\
\hline & & 19 & Greenhouse gas emissions \\
\hline & \multirow{3}{*}{ Resource depletion } & 20 & Water abstraction \\
\hline & & 21 & Soil erosion \\
\hline & & 22 & Genetic diversity \\
\hline & \multirow{2}{*}{ Benefits } & 23 & High Nature Value farmland \\
\hline & & 24 & Renewable energy production \\
\hline \multirow{5}{*}{ State / Impact } & Biodiversity and habitats & 25 & Population trends of farmland birds \\
\hline & \multirow{3}{*}{ Natural resources } & 26 & Soil quality \\
\hline & & 27.1 & Water quality - Nitrate pollution \\
\hline & & 27.2 & Water quality - Pesticide pollution \\
\hline & Landscape & 28 & Landscape - state and diversity \\
\hline
\end{tabular}

Source: European Commission (2006) Communication from the Commission to the Council and the European Parliament - Development of agri-environmental indicators for monitoring the integration of environmental concerns into the common agricultural policy $\{S E C(2006) 1136\}$, 
Agri-environmental indicators have to assess positive and negative effects of agriculture and should be sufficiently differentiated to be able to capture regional differences in environmental conditions (COM, 2000). Further, they should provide information: on the state of the environment in agriculture; on the wider context, particularly concerning the diversity of the EU's agri-ecosystems; for understanding and monitoring the linkages between agricultural practices and their effects on the environment; to support the global assessment process of agricultural sustainability; to assess the extent to which agricultural and rural development policies promote environmental friendly farming activities and sustainable agriculture (EC, 2006). Agri-environmental indicators are particularly significant for the formulation of policies and appropriate strategies. They contribute to this process in several ways (Piorr, 2003). Firstly, they give relevant information about the current conditions and trends in the environment to decision-makers and the general public, that are important for agricultural and rural development. Then, they provide a better understanding of the environmental consequences of policy measures and farmers' activities and guidelines for further initiatives, and the formulation of national and global development strategies. In addition, indicators enable monitoring and evaluation of the adopted measures' effectiveness and progress in achieving the set goals.

Although the environmental dimension often gets the most attention, the remaining two should not be neglected. For sustainable development of agriculture and entire rural areas, balance and coherence of all segments - economic, social and environmental - is necessary. According to the EU institutions, the core issues of the concept of sustainability are: maintenance (protection, renewal) of a combination of various forms of capital stocks, with a view to sustaining well-being, efficiency of the transformation process (avoiding inefficiency, promoting efficiency) and intra- and intergenerational equity (EC, 2001). Therefore, sustainable agriculture and rural development should respond to these requirements at the sectoral (agriculture) and territorial (rural areas) level.

The basis of the EU sustainable agricultural and rural development policy is the preservation of sufficient stocks of natural, human and financial capital. Thus, parameters that indicate the state of various types of capital and variations in capital stocks are at the beginning of the sustainability indicators list. These indicators are especially important since resources must be reasonably used, considering the uncertainty of substitution between different types of capital, of future demand and possibilities to increase efficiency of the transformation process. In the economic and social dimension they refer to human and man made capital. The number and age of people employed in agriculture, and education and training level of household owners, show quantitative and qualitative aspects of available human capital. Farmers' fixed assets and stocks in agriculture and farmers' fixed assets outside their core activity indicate the state of man made capital. Flow indicators complement the state indicators, pointing out the changes in stocks of different forms of capital. With regard to human resources, those parameters show the evolution of the number of people employed in agriculture and their agricultural education and skills. In relation to the man made capital, they describe the change in fixed assets and stocks in agriculture, the change in farmers' fixed assets outside their agricultural core activity and identify the rate of renewal of farm capital. 
Table 2. Economic and social indicators of sustainable agricultural and rural development in the European Union

\begin{tabular}{|c|c|c|c|}
\hline \multirow{4}{*}{ 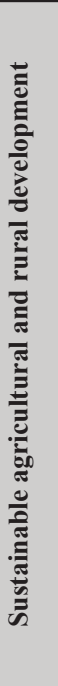 } & & Economic dimension & Social dimension \\
\hline & Stocks & \multicolumn{2}{|c|}{ State and flow indicators on stocks (quantity and quality) } \\
\hline & Efficiency & $\begin{array}{l}\text { Output indicators (quantity } \\
\text { and quality) } \\
\text { Competitiveness and } \\
\text { viability indicators }\end{array}$ & $\begin{array}{ll}\text { - } & \text { Indicators on employment } \\
\text { Indicators on institutional } \\
\text { efficiency }\end{array}$ \\
\hline & Equity & $\begin{array}{l}\text { Over space: } \\
\text { - Indicators on the viability } \\
\text { of rural communities } \\
\text { and the maintenance of } \\
\text { a balanced pattern of } \\
\text { development including } \\
\text { the agricultural sector's } \\
\text { contribution }\end{array}$ & $\begin{array}{l}\text { Over space/sectors: } \\
\text { - } \quad \begin{array}{l}\text { Indicators on access to } \\
\text { resources / services and } \\
\text { opportunities }\end{array} \\
\text { Social groups: } \\
\text { - Indicators on equal } \\
\text { opportunities } \\
\text { Ethics: } \\
\text { - } \quad \text { Labor conditions } \\
\text { Animal welfare indicators }\end{array}$ \\
\hline
\end{tabular}

Source: EC: Directorate-General for Agriculture (2001) A Framework for Indicators for the Economic and Social Dimensions of Sustainable Agriculture and Rural Development

Different forms of capital are used to provide various market and non-market outputs. In order to evaluate the efficiency of that transformation process, a group of efficiency indicators is created. Efficiency indicators in the economic sphere reveal the quality and quantity of the output, as well as sector competitiveness and production viability. Output indicators refer to the quantity of food and non-food outputs, the share of organic production and products carrying registered name, infringements on residues/contaminants legislation, food demand and productivity of different factors of production (capital, labor, land), as well as energy efficiency. Since agricultural production can be long-term sustainable only with renewable resources and a certain level of competitiveness, viability and competitiveness indicators are equally important. They show added value, composition of farm household income, farms' own resources, public stocks and farmers' terms of trade, for purchasing raw materials and selling agricultural goods. The viability of the current structure of the agricultural sector is specified by indicators of change in own resources of farms and financial stress. Social group indicators are focused on institutional efficiency, which refers to the regulatory framework, informal relationships and steering mechanisms, and providing employment opportunities.

Equity indicators are related to different issues and can be territorial, demonstrating whether economic and social development between rural and other areas is balanced or not, and sectoral, which show if development between sectors is balanced. Economic indicators are numerous. One group of these refers to population and indicates the total number, gender and age structure, evolution and skills of people in rural areas. Economic 
indicators of production show GDP, the share of agriculture and food industry in GDP, while in the field of employment, they illustrate the size and structure of the working population, agriculture and food industry employment in total (rural) employment, labor pressure and unemployment in these regions. A particular segment of economic parameters is the one with infrastructure indicators which reveal the number and the size of towns in rural areas, distance to urban centers and circumstances in transport, health and telecommunications sector services. The social dimension involves parameters of equity over sectors and space. They indicate a living standard in agricultural and rural communities, such as distribution of income, poverty rate and jobless households, along with education level and working hours of social groups. Finally, the last group of social indicators refers to the ethical concerns of society and demonstrates labor conditions and animal welfare.

The study of sustainability level of rural development in the EU countries for 2000-2012 period, conducted by Siudek, Czarnecki and Vashchyk (2016), showed that there are large disparities between member states by all the three dimensions. In terms of economic development, according to the synthetic index, Central and Eastern European countries (Lithuania, Romania, Slovakia, Poland and the Czech Republic) had the lowest results, while the Western and Southern Europe (Luxembourg, the Netherlands, France, Malta and Slovenia) were the most successful. Surprisingly, ecological conditions were the worst in the United Kingdom, Spain and France, as well as in Malta and Poland. On the other hand, the highest progress within the environmental dimension was achieved in the Scandinavian region (Finland and Sweden) and Latvia. Regarding social development, the research pointed out that countries which joined the EU recently - Romania, Croatia, Poland and Lithuania - had the worst results, while socially the most developed rural areas are those in the Benelux, Denmark and Sweden. The overall degree of rural sustainability was the lowest in Latvia and Romania, as well as in some old EU members like the UK, Luxembourg, the Netherlands and France. On the contrary, Hungary, Bulgaria, Italy, Greece and Ireland were the winners when it comes to sustainability of rural areas. The study also indicated that better environmental conditions were not necessarily related to higher economic development, as it might be expected. Besides that, economic condition was not the major cause of unsustainable rural development in the EU, but the environmental component which had the strongest impact.

\section{Conclusion}

Agriculture has always been one of the most important parts of the EU economy and a major force of rural development. Economic progress and globalization process have brought many positive changes to the agricultural sector in the EU, increasing the productivity and diversification. However, that success has often implied aggressive methods and practices that led to air and water pollution, soil erosion, destruction of natural habitats and disturbance of the ecosystem balance. Through the years, as the multifunctionality of agriculture has grown, it became clear that its role in the economy cannot be restricted only to the production of food. Considering the strong impact on the environment and a wide range of positive and negative effects on rural communities, long-term sustainability of agricultural activities must be taken into account. 
The current CAP goals and priorities encourage agricultural practices that are environmental friendly, that meet social demands and economic principles. Rural policy has been developed to provide maximum support to the rural areas to cope with contemporary economic, environmental and social challenges. Future reforms and development of the CAP should continue in the same direction, bringing strategies that keep up with the requirements of society and nature. Implementation of innovative solutions and increased technology usage on farms and in rural areas generally will be major determinants of progress and sustainability of rural communities. The improvement of quality of life in these regions is crucial for further development.

Observing trends, measuring how certain activities contribute to the sustainability and evaluating the results of the measures taken, are impossible without appropriate indicators. In the EU, numerous indicators have been defined to monitor the impact of agriculture on the environment and their interrelation, the efficiency of agricultural production, the competitiveness of rural areas, as well as social problems related to employment and living conditions in rural regions. The greatest attention was paid to the environmental dimension, which does not surprise considering the enormous influence of the agricultural sector on nature and growing environmental concerns. The significance of indicators emanates from their role in helping decision-makers when formulating policies and strategies, assessing the effectiveness of the measures taken and measuring progress over time.

Defining a set of standardized indicators, which can apply in all member states, provides a solid foundation for monitoring sustainability of agriculture and rural development across Europe. However, since biological, physical, climatic and socioeconomic conditions vary from one country to another, proposed indicators may not be equally suitable and applicable in all member states. Therefore, it is necessary to adapt given parameters to the particular circumstances of the country. Further work on indicators' development should be focused on overcoming this kind of limitations and on revision and update of indicators in order to respond to the changes and requirements of different regions.

\section{References}

Božić, D., Bogdanov, N. \& Ševarlić, M. (2011). Ekonomika poljoprivrede. Poljoprivredni fakultet, Univerzitet u Beogradu.

Commission of the European Communities (2000). Communication from the Commission to the Council and the European Parliament - Indicators for the integration of environmental concerns into the common agricultural policy /* $\mathrm{COM} / 00 / 0020$ final */. Brussels.

European Environment Agency (1999). Environmental indicators: typology and overview: Technical report No 25. European Environment Agency, Copenhagen, Denmark.

Edwards, G. A. (1987). The concept of integrated systems in lower input/sustainable agriculture. American Journal of Alternative Agriculture 2,148 - 152.

European Commission (1997). Agenda 2000. Luxemburg: Office for Official Publications of the European Communities. 
European Commission (2006). Communication from the Commission to the Council and the European Parliament - Development of agri-environmental indicators for monitoring the integration of environmental concerns into the common agricultural policy $\{$ SEC(2006) 1136\},COM/2006/0508 final/. Brussels.

European Commission (2013). CAP and Rural Development Policy reform deal for 2014-2020. European Commission, Brussels.

European Commission: Directorate-General for Agriculture (2001). A Framework for Indicators for the Economic and Social Dimensions of Sustainable Agriculture and Rural Development. European Commission, Brussels.

European Commission: Directorate-General for Agriculture and Rural Development (2013). Rural Development in the EU: Statistical and Economic Information Report 2013. European Union

Francis C. A., Sander D. \& Martin A. (1987). Search for a sustainable agriculture: reduced inputs and increased profits. Crops and Soils Magazine 39, 12-14.

Gafsi, M., Legagneux, B., Nguyen, G. \& Robin, P. (2006). Toward sustainable farming systems: effectiveness and deficiency of the French procedure of sustainable agriculture. Agricultural systems 90, 226-242.

Hayati, D., Ranjbar, Z. \& Karami, E. (2010). Measuring Agricultural Sustainability, Biodiversity, Biofuels, Agroforestry and Conservation Agriculture. Sustainable Agriculture Reviews, vol 5., 73-100, Springer, Netherlands.

Ikerd, J. (1993). The need for a system approach to sustainable agriculture. Agriculture, Ecosystems and Environment 46, 147-160.

Majkovič, D., Borec, A., Rozman, Č., Turk, J. \& Pažek, K. (2005). Multifunctional concept of agriculture: just an idea or the real case scenario?. Društvena istraživanja: časopis za opća društvena pitanja, broj 3 (77), 579-596, Zagreb.

Norman, D., Janke, R., Freyenberger, S., Schurle, B. \& Kok, H. (1997). Defining and implementing sustainable Agriculture. Kansas Sustainable Agriculture Series, Paper \#1, Kansas State University, Manhattan, KS.

OECD (1998). Agriculture in a Changing World: which Policies for Tomorrow? Meeting of the Committee for Agriculture at the Ministerial level. Press Communiqué, Paris, 5-6 March.

OECD (1999). Environmental indicators for Agriculture: Volume 1, Concepts and Framework. OECD Publications Service, Paris, France.

OECD (2000). Agricultural Policies in OECD Countries: Monitoring and Evaluation 2000: Glossary of Agricultural Policy Terms. OECD.

Piorr, H.-P. (2003). Environmental policy, agri-environmental indicators and landscape indicators. Agriculture, Ecosystems and Environment 98, 17-33.

Pretty, J. (1995). Regenerating Agriculture: Policies and Practice for Sustainability and Self-reliance. Earthscan Publications Limited, London.

Rasul, G. \& Thapa, G. (2004). Sustainability of ecological and conventional agricultural systems in Bangladesh: an assessment based on environmental, economic and social perspectives. Agricultural Systems 79, 327-351. 
Siudek, T., Czarnecki, E. \& Vashchyk, M. (2016). Assessment of the sustainability of rural development in the European Union member states. Oeconomia 15 (3), 101-113.

Tilman, D., Cassman, K., Matson, P, Naylor, R. \& Polasky, S. (2002). Agricultural sustainability and intensive production practices. Nature, 418, 671-677.

WCED [World Commission on Environment and Development] (1987). Report of the World Commission on Environment and Development: Our Common Future. Oxford University Press, Oxford.

Zhen, L. \& Routray, J. (2003). Operational Indicators for Measuring Agricultural Sustainability in Developing Countries. Environmental Management Vol. 32, No. 1, 34-46., Springer-Verlag, New York Inc. 